DOI: 10.12731/2227-930X-2016-1-8-17

\title{
HIGHER EDUCATION FUNDING IN IRAQ IN TERMS OF THE EXPERIENCE OF PARTICULAR DEVELOPED COUNTRIES
}

Atiya Abbas Gatea, Vrazhnova M.

Education funding is considered to be one of the issues that quite a few universities around the world have been preoccupied with as it is the basic element to fulfil their goals in this field.

Education expenditures clearly show how important education is thought to be in a particular country. This is an ongoing issue since it is related to changes in the global economy system and the increase in education expenditures in general and of higher education in particular, that, of course, affects the level of funding from the general budget of the country.

Keywords: funding; funding sources; funding solution.

\section{Introduction}

The issue of funding optimization of education in general and of higher education in particular is one of the major ones that a lot of countries around the world have to face regardless of the level of their economic development. In general, funding can be defined as a certain amount of funds designed to be spent to perform a specific job in order to achieve the desired economic, social or cultural goal or all of them combined.

From an administrative point of view funding can be described as an administrative duty that implies financial planning in order to obtain the funds from the relevant sources to provide for particular 
financial requirements and ensure an organization's continuous activity.

University funding can be defined as a combination of financial resources allocated for the university education from the general budget of the country as well as a number of other sources, such as donations, tuition fees, domestic and international grants by various organizations and foundations, economic activity revenues, loans.

The conventional view of education funding for is none other but receiving the funds and their use to implement and develop various projects. It is mainly focused on determining the best source of funding from a number of possible ones.

At the moment, higher education in Iraq is facing certain difficulties while building up the resource support for the universities. But that is not the most significant thing. The country's existing approaches to financing are thought to be quite conservative. Thus, the financial mechanism should be built up that could combine conventional methods with non-conventional ones that take into account the funding model of the developed countries' higher schools.

\section{Kinds of funding}

The researchers of higher education financing have distinguished the following types of universities funding:

- budgetary funding;

- educational loans;

- educational services export;

- provision of material-and-technical services aimed at collecting funds;

- state registered financial obligations in the field of education;

- grants and programs;

- external funding through a system of both international and regional financial institutions, such as the International Monetary 
Fund or the International Bank for Reconstruction and Development, as well as some other regional organizations in addition to the international funding programs which are presented in the form of subsidies and investments, for example, the Media program $^{1}$, started by the European Union within the framework of the Euro-Mediterranean partnership ${ }^{2}$.

\section{The higher education funding sources are as follows:}

\section{Governments}

The observational studies carried out by international organizations in many countries around the world have shown that there are three models of higher education system funding on the basis of total revenues:

1. Funding received from the central government.

2. Funding received from both the central government and local authorities.

3. Funding received through cooperation between the central government, regional and local authorities.

\section{Students}

Students are the primary users of the learning process and, therefore, they are the most important sources of university funding in many countries around the worlds, including the developed ones. The most important funds inflow from the students are as follows:

${ }^{1}$ The media cooperation program, started by the European Union to assist in activities of some Arab countries the EU has partnership relations with (import, export, etc.). According to this program Egypt received a total of 352.2 (mln. EUR) in 20002006, Majdi Bilal, the European Union strategy towards the countries of the Southern Mediterranean region.

${ }^{2}$ The Euro-Mediterranean partnership - the process of state-to-state cooperation, started in 1995 between the European Union and the North African Mediterranean and West Asian countries, aimed at strengthening economic ties. 
A) The tuition fee. This system is introduced in most developed countries as well as some developing countries. Recently, they have been joined by the Arab countries, despite the fact that it has caused a lot of resistance within these countries, where the free form of education was widespread.

B) Student loans. A student pays for their university education through loans obtained while they are studying. Ways and means of paying these funds back might be different in these countries.

C) Studies bonds. A bond is a voucher that enables one to buy some particular services. The bonds system intensifies competition between higher education institutions and makes them take greater responsibility for the quality of education provided. Study bonds. A bond is a voucher that gives the opportunity to buy some educational services. bond system intensifies competition between higher education institutions and forces them to take greater responsibility for the quality of education provided.

\section{Universities}

Through self-funding, making funds on their own. In this case, universities have the right to manage their financial resources in their sole discretion, not according to the rules defined by the state budget. This allows universities to engage in other activities in addition to the primary ones, that helps them earn additional funds, making it possible to finance certain activities. Thus, universities become production centres, implement research results; provide advisory services, buy and rent plots of land, buildings, etc.

\section{Grassroots fundraising}

The most important of these models are:

- grants and donations;

- trade unions and non-government organizations;

- alumni communities;

1. External funding 
In many developing countries, university funding is based on loans coming from abroad as well as and assistance from outside. Such international institutions and organizations as the World Bank, the European market, UNESCO, etc. provide interest-free, long-term and easy-to-pay loans. However, this process needs careful studying to avoid unnecessary costs and financial losses, on the one hand, and, on the other hand, one should find out about the positive and negative sides of the proposed loan to make sure there is no secret criminal purpose of the external foreign-funding of higher education system.

\section{Sources of higher education funding in Iraq and some Arab countries}

The responsibility for the educational, research and other educational activities funding in Iraq was taken completely by the state, in particular prior to the introduction of legislation allowing the establishment of private universities and the implementation of new technologies in the field of higher education (the parallel education and e-learning). It is the government that transfers the required funds out of the state budget for universities and other educational institutions by means of the current budgetary allocations, investment tax credits. The state monitors their yearly increasing, as the rise in the number of students and the average level of applicants implies a corresponding increase in investment from the state budget in the field of higher education, if its quality and decent educational training level need to be preserved. The Japanese experience of investing in the education sector in order to accelerate the economic development of the country is the most significant evidence of the role of these institutions. The last decade saw wide introduction of private funding in the country considered as one of the main sources of education funding; as a result, in addition to the state-funded educational institutions there appeared organizations with mostly private funding. 
Table 1.

Pet. comparison of the funds allocation for higher education in some Arab countries within 2008-2012. ${ }^{3}$

\begin{tabular}{|c|c|c|c|}
\hline \multirow{2}{*}{ State } & \multirow{2}{*}{ Year } & \multicolumn{2}{|c|}{ Allocations } \\
\cline { 3 - 4 } & 2010 & GDP pct. & State allocations pet. \\
\hline Tunisia & 2008 & 3.4 & 5.21 \\
\hline Algeria & 2008 & 6.5 & 3.20 \\
\hline Saudi Arabia & 2009 & 1.5 & 3.19 \\
\hline Syria & 2009 & 3.4 & 7.18 \\
\hline Oman & 2009 & 4.5 & 7.25 \\
\hline Morocco & 2008 & 8.3 & 9.11 \\
\hline Egypt & 2012 & 5.3 & 11 \\
\hline Iraq & & &
\end{tabular}

In Iraq, as in most Arab countries, the state continues to be the main source of education funding. In recent years, there was an increase in the amount of education funding in Iraq: government allocations rose from $6.8 \%$ in 2008 to $11 \%$ in 2012 , though it is still quite low if compared with other Arab countries. According to the data provided by UNESCO (Table 1), allocation of funds for education in relation to a country's GDP (2008-2012) varies between 2.6\% and 5\% in Tunisia, Saudi Arabia and Yemen, whereas it amounts to $5.3 \%$ in Iraq. But in Morocco and Egypt investment in education exceeds the one in Iraq (for example, the government in Morocco allocates over 7\% in the education sector). With regard to foreign countries, according to the annual report of the Organization for European Cooperation and Development (OECD) $4.7 \%$ is allocated to education in the United States, $2.7 \%$ in South Korea, whereas in Belgium, Denmark and France this ratio varies between $2.7 \%-6 \%$ and $1.4 \%$ in Turkey.

\section{Conclusion}

Every country in the world carries out its economic policy and makes every effort to implement it in order to ensure the popula-

\footnotetext{
${ }^{3}$ UNESCO Institute for statistics, UNESCO, Paris.
} 
tion's well-being. Its implementation is done in the form of projects designed to meet the needs and financial capabilities of the country. Funding can be characterized as the blood streaming in the veins of the project. Therefore, it can be stated that funding plays a significant role in the country's development policies and is implemented as follows:

1. Capital provision to carry out project activities that:

- provide new jobs that reduce the number of the unemployed;

- contribute to the economic development of the country;

- contribute to the fulfilment of economic goals set by the state.

2. Funding provides the well-being of the society by enhancing their subsistence level (housing, jobs provision, etc.).

Taking the above-mentioned facts as the base we can briefly introduce both positive and negative consequences of the higher education sector state and private funding, as well as try to present solutions to the problems that might be encountered.

\section{- Education sector state funding}

Advantages

- The financial barriers get eliminated to people who want to get an education (that leads to the increase in the number of educated people as well as there appears an opportunity to carry on with education).

- It is considered to be an effective means for the promotion of affordable universal education.

- It contributes to meeting the public requirements to provide compulsory education.

- It enables talented young people to carry on with their education.

- It ensures a smooth transition of professionals into various sectors of economic and social activities.

- It ensures quantity and quality workforce planning.

- It contributes to scientific and technological progress. 
- It helps optimize the number of students in each field of study.

\section{Disadvantages}

- Insufficient economic motivation or its total lack that would enhance the effectiveness of education on the part of both students and teachers.

- The current system does not provide the motivation that would make it possible to enhance the university lecturer impact, as they are aware of the fact that any additional effort is unable to increase their material wealth.

- Educated personnel brain drain.

- Students and teachers are not eager to meet the educational standards.

\section{Problem solution}

- The student must bear some minor expenses, such as buying books and stationery.

- The student should pay the education costs if they fail to meet the educational requirements.

- The student should be denied a scholarship if they fail to show good academic results, just as it is done in Russia.

- The student should pay for their second and third attempts while taking an exam.

- Better opportunities should be provided for gifted students to develop their professional and scientific abilities.

\section{- Education sector private funding}

\section{Advantages}

- It provides economic incentives in the field of education and, as a result, it reduces the professional personnel brain drain.

- It stimulates the student to put more effort to achieve the effective use of educational material. 
- It makes the student to carefully choose the kind of education that best fits their capabilities and expectations.

- It is an important factor for improving the quality of the student's studying in order to maximize the use of the acquired knowledge in practical life.

\section{Disadvantages}

- It creates certain financial hindrances to getting education and its further continuation.

- It makes it difficult for promising young people to get access to education.

- It limits the employees training and retraining possibilities.

- It fails to provide sufficient opportunities for the development of all branches of knowledge required by society (primarily, basic sciences).

\section{Problem solution}

- There should be a specific system based on the student's participation in the education funding aimed at creating their sense of responsibility.

- Tuition fees should be reduced for students who are having financial constraints but are characterized by their high academic potential; this should take effect after they have passed their exams to provide an incentive to enhance their scientific activity.

- Students should be given an opportunity to get an off-hour job at their university.

- There should be a selection of funding sources that will not directly or indirectly affect the quality of education.

\section{References}

1. Al-Ani Tarek Zhassim, Nuaimi Salah Abdel-Kader. Higher education and development in Iraq (the reality and the challenges and prospects). UNESCO's Office for Iraq in December 2013. 
2. Al-Shammari Sazhad. The project studies the financing of education in the light of globalization. Journal of development projects. Wednesday, February 27, 2013.

3. Al-Janabi Kazem. Iraqi universities and sources of self-financing. Journal of Iraqi national conference. Iraq 01.08.2009.

4. The Hany Khadr Elias. Higher Education in Iraq, dilemmas and consequences. Forum Iraqi elite. Iraq 06.21.2015.

5. Bilal Abdul-Hamid Majdi. EU Strategy for the Southern Mediterranean countries. Egyptian Association 'Increasing the participation of the community'. Egypt 2008.

6. Alhauli Abdullah Alyan. Lecture on the financing of education. Palestinian University in 2011.

\section{DATA ABOUT THE AUTHORS}

Atiya Abbas Gatea, Master of the Department of Sociology and Administration (Moscow Automobile and Road Construction State Technical University)

University of Thi-Qar

Nasiriyah, Thi-Qar, Iraq

atyia83@mail.ru

Vrazhnova Marina, Head of the Department of Sociology and Administration

Moscow Automobile and Road Construction State Technical University

64, Leningradsky prospect, Moscow, 125319, Russian Federation

ok@madi.ru 